\title{
On Special Semantic Meaning of Securities English
}

\author{
Guineng Mei \\ Foreign Languages College, Zhejiang Gongshang University, China \\ Email: guinengmei@sina.com
}

\begin{abstract}
This paper argues that securities English has its own semantic meaning especially nouns, adjectives, adverbs and verbs have their unique semantic meaning that can't be owned by their common words and that it is imperative this linguistic features be grasped in order that this kind of English should be faithfully and correctly understood and translated and proficiently applied.
\end{abstract}

Index Terms — securities English, semantic meaning, linguistic features, linguistic sense, culture

Securities are defined as any note, stock, treasury stock, security future, bond, debenture, certificate of interest or participation in any profit-sharing agreement or in any oil, gas, or other mineral royalty or lease....(Section 3a item 10 of the 1934 Act). In Collins Cobuild English Dictionary, securities are defined as stocks, shares, bonds, or other certificates that you buy in order to earn regular interest from them or to sell them later for a profit. Therefore security includes note, stock, treasury stock, security future, bond etc. Securities English words have special semantic meaning, so we are to pay special attention to the semantic meaning of securities English. If we want to understand correctly securities English, we are to learn securities English, because we can't get the meaning of securities English by referring to dictionaries. Here I sum up the main features of the semantic meaning of securities English.

\section{Nouns HaVe SPECIAL SEMANTic MEANing}

1 The red herring is an initial prospectus containing all the information about the company except for the offer price and the effective date, which aren't known at that time. With red herring in hand, the underwriter and the company attempt to hype and build up interest for the issue. They go on a road show where the big institutional investors are courted.

Here red herring does not refer to the fish that is smoked and dried by people but an initial prospectus of a company that is going to go public because on its cover of the prospectus there is a passage of red words to note that the prospectus has not gone into effect and is to be perfected or revised.

2 Investors usually focus on weekly and monthly charts to spot long-term trends and forecast long-term price movements. Because long-term charts cover a longer timeframe with compressed data, price movements do not appear as extreme and there is often less noise.

Here noise is not sound but the price fluctuation on daily charts that interfere with your correct judgment of the long-term trends of the stock.

3 The console is getting no IPO allotment may be a blessing in disguise. After all, IPOs may prove too risky for individual investors. In the days of dot-com mania, investors could throw money into an IPO and be almost guaranteed killer returns. Now the tech bubble burst and the IPO market returned to normal.

Here killer means much profit.

4 International direct investment commonly involves the movement of production factors, while in the case of international portfolio investment, investors simply purchase shares or bonds issued by a foreign company, which can be liquidated at market prices at any time.

Here portfolio investment refers to securities investment.

Here are some other nouns that have special semantic meaning: maturity (the money you have invested is ready to be paid), note (an official document with a particular purpose), correction (adjustment), share (any of the units of equal value into which a company is divided and sold to raise money. People who own shares receive part of the company's profits), futures (goods or shares that are bought at agreed prices but that that will be delivered and paid for at a later time), exchanges (a building where people meet to buy and sell stocks) etc.

Because of flipping, it's a good rule not to buy shares of an IPO if you don't get in on the initial offering. Many IPOs that have big gains on the first day will come back to earth as the institutions take their profits.

Here flipping means staging i.e. buying shares of an IPO.

\section{Adjectives Usually Have Special Semantic Meaning}

Adjectives are used to describe or modify nouns. They play a vital role in modifying nouns. In securities English, we can't make sense of adjectives solely by their literal meanings. For example: 
1 Private companies try to go public or perform an "Initial Public Offering”(IPO) to sell shares of their stock to the public in order to raise money for the company. Public companies have thousands of shareholders and are subject to strict rules and regulations. They must have a board of directors and they must report financial information every quarter and they must be overseen by governing bodies similar to SEC -- Securities Exchange Commission.

Private companies here do not refer to companies that are owned by a private person but companies that have not gone public or been listed, so we can't buy or sell the shares of their stock of the companies. Obviously some state-owned companies that have not gone public / been listed are still private companies. Public companies are not companies that are owned by the public but that the shareholders can buy or sell the shares of their stock of the companies. Some public companies are still owned by a private person or some private people although these companies have gone public or been listed.

2 A daily candlestick is based on the open price, the intraday high and low, and the close.

Some investors consider the closing level to be more important than the open, high or low. By paying attention to only the close, intraday swings can be ignored. Line charts are also used when open, high and low data points are not available.

Here high means the highest and low the lowest.

3 Futures price have a price change limit that determines the prices between which the contracts can trade on a daily basis. The price change limit is added to and subtracted from the previous day's close, and the results remain the upper and lower price boundary for the day. Say that the price change limit on silver per ounce is $\$ 0.25$. Yesterday the price per ounce closed at $\$ 5$. Today's upper price boundary for silver would be $\$ 5.25$ and the lower boundary would be $\$ 4.75$. At any moment during the day the price of futures contracts for silver reaches either boundary, the exchange shuts down all trading of silver futures for the day.

Here the upper means the top or highest and lower the lowest.

4 Penny stocks are extremely speculative stocks. Investors in speculative stocks are "high rollers". Investors anticipate a dramatic increase in the earnings of a company even though there is little or no business performance track record or there is a record of erratic earnings. This hope may arise for a variety of reasons such as the company is developing a new product or service that shows early signs of success, or there is evidence that a market has seen the bottom and is poised to take off into a bullish phase.

Bullish phase refers to the phase in which the stock will rise.

Point \& Figure Charts focus on price movements, which is easier to identify support and resistance levels, bullish breakouts and bearish breakdowns.

Bullish breakouts refers to the fact that the stock has broken through and has been in the trend to rise while bearish breakdowns is just the opposite that the stock has broken through and has been in the trend to go down.

5 A private company can get publicly-listed in a very relatively short time period by reverse merger. The private company that has strong prospects and is eager to raise financing buys a publicly-listed shell company, usually one with no business and limited assets. Together the two companies become an entirely new public corporation with tradable shares. There are others like rebound, collapse, be hung up, come out handsomely, reversal, peak out, bottom out, thinly traded.

Reverse merger refers to the fact that a private company goes public by buying a publicly-listed shell company.

6 The target company's management may seek out a white knight who will offer an equal or higher price for the shares than the hostile bidder.

White knight refers to a friendly company the target company looks for to make a tender to fight against hostile bidder.

7 High turnover in excess of $100 \%$ is also a red flag for high brokerage costs.

You should choose a fund that has been well-managed by the same manager over a period of time. Funds that play musical chairs with their managers should raise red flags.

Here red flag refers to warning, because red implies danger.

8 A daily candlestick is based on the open price, the intraday high and low, and the close. White (clear) candlesticks form when the close is higher than the open and black (solid) candlesticks form when the close is lower than the open. The white and black portion formed from the open and close is called the body (white body or black body). The lines above and below are called shadows and represent the high and low.

But in china we use red candlesticks instead of white to express the fact that when the close is higher than the open, and green instead of black when the close is lower than the open.

9 The accumulated earnings of the stock are two dollars per share.

Accumulated earnings refer to the earnings that has not been allotted.

10 The bottom line of the stock this year is 220,356,300 dollars.

Bottom line refers to net earnings, for in the annual report the bottom line is net earnings.

11 The listed company has a classified loan, so the stock of the company is weak.

A classified loan is a loan that is not paid in due time.

12 After a steep, rapid decline of the stock price, dead cat bounce appeared.

Dead cat bounce refers to a moderate strong bounce. 
13 An upside gap is followed by a downside gap, which is considered a major top reversal signal, which is called abandoned baby pattern.

Abandoned baby pattern refers to the signal in the candlesticks that the price of the stock will reverse to rise.

\section{ADVERBS}

1 Some new dot-com millionaires in Silicon Valley cashed in on their latest IPO. The phenomenon spawned the term "siliconaire" which described the dot-com entrepreneurs who suddenly found themselves living large due to IPOs from their Internet companies.

Living large means living a very rich life.

2 With an initial margin of $\$ 2,000$ in June, Joe buys one September contract of gold at $\$ 350$ per ounce, for a total of 1,000 ounces or $\$ 350,000$. By buying in June, he is going long, with the expectation that the price of gold will rise by the time the contract expires in September.

Here going long means being a patient investor who holds the view that the trend of the futures will be rise and will not sell in a short period of time. Along position involves inflows greater than outflows in a currency.

3 Suppose that with an initial margin of $\$ 3,000$, Sara sold one May crude oil contract at $\$ 25$ per barrel for a total value of $\$ 25,000$. By March, the price of oil had reached $\$ 20$ per barrel and she bought back the contract which was valued at $\$ 20,000$. By going short, she made a profit $\$ 5,000$.

Here going short means the fact that the investor anticipates that the price of the stock will be in a down trend, and he sells the stock first, and then he buys the stock when its price has fallen and will be up.

4 The investors may buy low and sell high if the company does well. (Mingyao Chen, Fagong Liu, 2003: 58)

Here buy low means buy when the stock price is low, and sell high means sell the stock when its price is high.

\section{VERBS}

1 The government tried to bull the market to stimulate investors to put their money to the stock.

To bull the market means to make the price of the stock rise.

2 Some speculators attempt to bear the stock market.

To bear the stock means to go short in the stock market.

3 By technical analysis profits can be made in any market by positioning ourselves in the direction of the price trend.

To position oneself means to build position in the stock market.

From we can see that securities English has special semantic meaning. We should pay special attention to the special semantic meaning of the securities English in order to correctly understand, use and translate securities English.

\section{REFERENCES}

[1] Fang Chunxiang. (2007, 8). Securities English. Beijing: International Business University.

[2] Zhen Yuequan and others. (2006, 4). English for International Investment. Shanghai: Shanghai Education Press

[3] Jae K. shim,. Joel G. Siegel. (2010). Dictionary of international Investment Terms .Shanghai University of finance \& economics Press.

[4] Chen Mingyao, Liu Fagong. (2003). International Banking English. Jilin People's Publishing house.

[5] Zhen Gangyi, Wang Huabin. (2006). Selection of Examples of Banking English. Beijing: China's Water Conservancy and Water Power Press.

Guineng Mei was born in Guidong County, Hunan Province, China in 1963. He received his M.A in linguistics from Hunan University, China in 1996.

$\mathrm{He}$ is currently an associate professor in Foreign Languages College, Zhejiang Gongshang University, Zhejiang, China. His interests include English linguistics, Applied linguistics, and translation skills. 